\title{
Structural changes of the consumer market of Russia: from post crisis development to the sanctions period
}

\author{
Yuri I. Treshchevskiy \\ Doctor of Economic Sciences, Professor \\ Voronezh State University \\ Chair of Economics and Organizational Management \\ Voronezh, Russia \\ utresevski@yandex.ru
}

\author{
Sergey N. Papin \\ Student \\ Economic Department \\ Voronezh State University \\ Voronezh, Russia \\ serezha-papin@mail.ru
}

\author{
Ekaterina O. Penina \\ Student \\ Economic Department \\ Voronezh State University \\ Voronezh, Russia \\ penina1998@yandex.ru
}

\begin{abstract}
In the article the tendencies of the development of the consumer market of the Russian regions are studied. The study covers the periods of the economic growth since 2010 till 2013 and the introduction of the economic sanctions and the imposition of the counter-sanctions in 2014-2015. For the research the method of the cluster analysis is used, the results of which showed that in Russia five groups (virtual clusters) of regions are isolated according to the criteria characterizing the parameters of the consumer market suggested by the authors. The changes in the macroeconomic and political conditions lead to considerable transformations of the consumer market of the suggested groups of Russian regions according to the level of its development and its structure. The regions-leaders keep their dominating position at any changes of the economic and political competitive position. The regions-outsiders under favourable conditions move closer to the leading group. In contrast during the worsening of the economic conditions the group of the outsiders is widened due to the regions of an average development level. The character of the structural changes of the consumer market depends considerably on the classification group to which the region belongs.
\end{abstract}

Keywords - consumer market, region, virtual cluster, structure of consumer market

\section{INTRODUCTION}

The problems of the consumer market are studied during several centuries. It can be noted that the elements of the analysis of this type of the market are found already in the classical papers of the economic theory.
Later the value of the individual and social consumption including the public expenses for its functioning was analysed by J. Keynes (1) и J. Stiglitz (2). In the result of the implementation of their conception the consumer market became the object of the governmental regulation in many developed countries which is as much important as the financial and monetary sectors of the economy.

Without downplaying the importance of the governmental regulation of the consumer market it is worth paying attention to the research of M. Weber (3) who theoretically explained the importance of political unions for the creation of a special system of consumption resulting from their position in the external environment. It is worth mentioning that the results of the actions taken at the macro level are various not only for some individuals but also for large subsystems of the country. Earlier the coauthors noted that the regions of Russia present very heterogeneous systems in the economic and institutional sense (4). The consequences of this heterogeneity are considerable differences in the production and also in the innovative activity (5). Below we present the analysis of the changes of the consumer market of the Russian regions during the post crisis growth (2010) and the sanctions period (2015).

\section{MATERIALS AND METHODS}

For the analysis of the specificity of the consumer market of the regions of Russia the method of the cluster analysis suggested by I. Mandel (6), M. Oldenderfer, R. Blashfield (7), E. Hartigan (8) is used. For the study of the Russian regions 
this method was used by us (5) and by other researchers, in particular by O. Golichenko, I. Shchepina (9).

In the process of the analysis the official data characterizing the economic situation of the regions of Russia was used (10). The processing of the data was made with the help of the program "Statistika 10".

The common algorithms of the analysis included the following actions.

1. Calculation of the parameters of the consumer market. For the analysis of the parameters of the consumer market the following coefficients (presented in Table 1) were taken.

\section{TABLE 1 - STRUCTURE OF THE INDICES OF THE CONSUMER MARKET}

\begin{tabular}{|c|c|}
\hline Coefficient & Index \\
\hline Var1 & $\begin{array}{l}\text { Income of the population per capita (rubles per } \\
\text { month) }\end{array}$ \\
\hline Var2 & $\begin{array}{l}\text { Consumer expenses per capita of the } \\
\text { population (rubles per month) }\end{array}$ \\
\hline Var3 & $\begin{array}{l}\text { Number of cars in property per } 1000 \text { of } \\
\text { population (items) }\end{array}$ \\
\hline Var4 & $\begin{array}{l}\text { Meat and meat products consumption per } \\
\text { capita }(\mathrm{kg} / \text { year })\end{array}$ \\
\hline Var5 & Meat and dairy products per capita (kg/year) \\
\hline Var6 & Total area of housing units per capita $\left(\mathrm{m}^{2}\right)$ \\
\hline Var7 & $\begin{array}{l}\text { The turnover of the retail sales per capita } \\
\text { (rubles per year) }\end{array}$ \\
\hline Var8 & $\begin{array}{l}\text { Volume of consumer services per capita } \\
\text { (rubles per year) }\end{array}$ \\
\hline Var9 & $\begin{array}{l}\text { Volume of transport services per capita (rubles } \\
\text { per year) }\end{array}$ \\
\hline Var10 & $\begin{array}{l}\text { Volume of communication services per capita } \\
\text { (rubles per year) }\end{array}$ \\
\hline Var11 & $\begin{array}{l}\text { Volume of communal services per capita } \\
\text { (rubles per year) }\end{array}$ \\
\hline
\end{tabular}

2. Leveling of all the indices to a comparable type by means of a standard rationing procedure.

3. Use for the construction of the virtual clusters of the Kmean methods permitting to minimize the dispersion inside clusters.

4. Construction of a tree diagram allowing to determine a number of virtual clusters. The type of a tree diagram in every year showed that in Russia during the whole analyzed period five virtual clusters are clearly and statistically verified and isolated. They unite the regions with similar parameters of the consumer market.

5. Analysis of the statistical results of the virtual cluster creation. The use of the analysis of the Fisher criterion showed a high level of the dependence of the obtained results (diapason of criterion from 6,5 to 95,3).

6. Ranking of the virtual clusters according to the mean standard values chosen for the analysis.
7. Selection in a cluster of the nucleus including the regions which are constantly located in the group of regions. Besides in every cluster a sub nucleus is isolated. The regions from the sub nucleus are expected to be included into the cluster for at least three years during the period in question. The regions being from time to time the part of the cluster are thought to be peripheral ones. So a part of the regions make up the periphery of different clusters.

\section{RESULTS AND DISCUSSION}

The virtual clusters of the consumer market of Russian regions for the period 2010-2015 are studied below.

The analysis of the indices of the consumer market showed that five clusters can be selected. The most developed group of regions is cluster 1 and it includes the "nucleus" consisting from five regions (Moscow, Kamchatka Krai, Khabarovsk Krai, Magadan and Sakhalin oblast). The "sub nunleus" consists of the Republic of Saha and Primorsky krai.

\section{TABLE 2 - MEAN STANDARD VALUES OF THE} INDICES OF THE CLUSTER 1

\begin{tabular}{|l|l|l|l|l|}
\hline \multicolumn{5}{|c|}{ Cluster 1} \\
\hline Index & 2010 & 2013 & 2014 & 2015 \\
\hline Var1 & 0,558117 & 0,543845 & 0,652509 & 0,751032 \\
\hline Var2 & 0,508500 & 0,521585 & 0,504829 & 0,589067 \\
\hline Var3 & 0,577898 & 0,594784 & 0,536826 & 0,516680 \\
\hline Var4 & 0,471074 & 0,590909 & 0,489437 & 0,407143 \\
\hline Var5 & 0,452696 & 0,511234 & 0,344608 & 0,297665 \\
\hline Var6 & 0,613636 & 0,667420 & 0,654908 & 0,559464 \\
\hline Var7 & 0,493392 & 0,539123 & 0,464791 & 0,554335 \\
\hline Var8 & 0,530783 & 0,367607 & 0,594399 & 0,585529 \\
\hline Var9 & 0,578805 & 0,672363 & 0,792762 & 0,771402 \\
\hline Var10 & 0,469983 & 0,428355 & 0,485862 & 0,538057 \\
\hline Var11 & 0,588183 & 0,573638 & 0,679447 & 0,693718 \\
\hline $\begin{array}{l}\text { Sum } \\
\text { mean } \\
\text { standard } \\
\text { values }\end{array}$ & 5,843069 & 6,010864 & 6,200377 & 6,264091 \\
\hline
\end{tabular}

In total the number of the regions which belong to the cluster 1 reduced from 11 in 2010 and 2013 to 8 in 2014 and to 6 in 2016.

The Table 2 presents mean standard values of the indices in different years for cluster 1 .

As the data from the Table 2 show the average standard values in all groups grow although at a slow pace. This fact demonstrates the growth of the gap of the general level of consumer market development in the regions of this cluster in respect to other regions.

The structure of the consumer market for the given time period changed a lot. In general almost all the indexes improved. At the same time the constant worsening of the 
proportions of meat and milk consumption are observed. This in the whole is a negative characteristic of the consumer market of the regions of the given cluster.

In total the cluster with a high average income per capita and high expenses per capita, developed servicing sphere and high turnover of the retail sales but with low indices of the consumption of the basic food products (meat and milk in our situation) can be seen.

\section{Cluster 2 is a sub leader in the consumer market}

The "nucleus" of the cluster 2 is made up of 8 regions (Belgorod, Voronezh, Lipetsk, Rostov oblasts, republics of Komi, Bashkortostan, Tatarstan, Krasnodar Krai). The "sub nucleus" consists of the Kursk, Moscow and Sverdlovsk regions.

TABLE 3 - MEAN STANDARD VALUES OF THE INDICES OF THE CLUSTER 2

\begin{tabular}{|l|c|c|c|c|}
\hline \multicolumn{5}{|c|}{ Cluster 2 } \\
\hline \multicolumn{1}{|c|}{ Indices } & 2010 & 2013 & 2014 & 2015 \\
\hline Var1 & 0,263931 & 0,228392 & 0,346440 & 0,388035 \\
\hline Var2 & 0,332316 & 0,299236 & 0,400524 & 0,461684 \\
\hline Var3 & 0,539910 & 0,501898 & 0,531242 & 0,519823 \\
\hline Var4 & 0,492064 & 0,485328 & 0,529930 & 0,539560 \\
\hline Var5 & 0,592655 & 0,554373 & 0,609069 & 0,641724 \\
\hline Var6 & 0,640701 & 0,764685 & 0,773390 & 0,629687 \\
\hline Var7 & 0,380771 & 0,384566 & 0,445092 & 0,513834 \\
\hline Var8 & 0,617600 & 0,280350 & 0,710390 & 0,692805 \\
\hline Var9 & 0,213176 & 0,163849 & 0,247392 & 0,285908 \\
\hline Var10 & 0,190590 & 0,201371 & 0,253022 & 0,269996 \\
\hline Var11 & 0,334078 & 0,292149 & 0,460693 & 0,446187 \\
\hline $\begin{array}{l}\text { Sum of the } \\
\text { average } \\
\text { standard } \\
\text { values }\end{array}$ & 4,597791 & 4,156197 & 5,307183 & 5,389243 \\
\hline
\end{tabular}

In 2013 the growth of the competitive economic environment a sharp increase of the number of the regions in comparison with year 2010 took place. 23 new regions were included into its content mainly from the clusters 3 and 4. However, already in 2014 these regions returned to clusters 3 and 4. In 2014-2015 the regions with a high level of the economic development (Republic of Saha (Yakutia), SaintPetersburg and Murmansk oblast) moved from the cluster 1 to the cluster 2 .

The values of some indices of the consumer market of the cluster 2 are presented in Table 3 .

In 2010 the cluster 2 was almost two times weaker than the cluster 1 upon the average income per capita. Its weakest characteristics were the volumes of the transport services and communication services. However this cluster had the leading positions in the meat consumption and in the volume of the communal services.
Due to the inflow of a big number of regions in 2013 a considerable growth of the area of the housing units in comparison with 2010 was observed. During 2013-2015 the leading position of the cluster upon this index still remained.

In 2014 due to the transfer of a number of relatively weak regions into the clusters 3 and 4 the level of the development of the consumer market of the cluster 2 sharply increased (in 2014 and 2015 the sums of the mean standard values considerably grew). The growth of separate meaning of housing communal services grew especially fast.

At the same time a relative reduction of the total area of housing units is observed. In other words the consumption of the resource which is not only the consumer one but also an investment one reduced.

Cluster 3 is in the middle from the point of view of the development of the consumer market. The "nucleus" of the cluster 3 makes up 7 regions: Bryansk, Vladimir, Ivanovo, Kostroma, Tula, Amur oblasts and Jewish Autonomous oblast which kept their position in the cluster.

The "sub nucleus" is formed by the Kaluga, Chelyabinsk, Tambov, Arkhangelsk, Tyumen oblasts, republic of Adygea, Primorsky Krai.

Taking into account the number of the regions the cluster 3 is very instable. In 201321 regions from the cluster 3 transferred mainly into the cluster 2 which is placed higher according to the level of the development of the consumer market. In 2013-2014 the number of the regions was relatively stable. The regions which left this cluster earlier returned there in 2015. For this moment it included 32 regions. The indices of the development of the cluster 3 are presented in Table 4 .

In 2010 the cluster 3 occupied the leading position judging from the area of the housing units. In compliance with the largest part of the indices this cluster was close to the cluster 4. The weakest positions of the cluster in 2010 were the volume of transport services and communication services.

TABLE 4 - MEAN STANDARD VALUES OF THE INDICES OF THE CLUSTER C

\begin{tabular}{|l|l|l|l|l|}
\hline \multicolumn{5}{|c|}{ Cluster 3 } \\
\hline Indices & 2010 & 2013 & 2014 & 2015 \\
\hline Var1 & 0,184231 & 0,317869 & 0,263945 & 0,252658 \\
\hline Var2 & 0,245447 & 0,304871 & 0,308433 & 0,324133 \\
\hline Var3 & 0,494228 & 0,396365 & 0,467766 & 0,508954 \\
\hline Var4 & 0,363636 & 0,271396 & 0,297535 & 0,341964 \\
\hline Var5 & 0,503753 & 0,308935 & 0,335784 & 0,387038 \\
\hline Var6 & 0,675854 & 0,721532 & 0,725460 & 0,626727 \\
\hline Var7 & 0,298062 & 0,386824 & 0,357712 & 0,378998 \\
\hline Var8 & 0,323078 & 0,337221 & 0,471741 & 0,409241 \\
\hline Var9 & 0,111273 & 0,200422 & 0,168342 & 0,153832 \\
\hline Var10 & 0,169839 & 0,233063 & 0,217290 & 0,217985 \\
\hline Var11 & 0,314629 & 0,382974 & 0,399548 & 0,350191 \\
\hline $\begin{array}{l}\text { Sum of } \\
\text { mean } \\
\text { standard } \\
\text { values }\end{array}$ & 3,684030 & 3,861472 & 4,013555 & 3,951721 \\
\hline
\end{tabular}


In 2013 the converging of the cluster 3 with the cluster 2 took place. A relative growth of the average income per capita and the volume of the transport services per capita drew the attention of the researchers. The increase was accompanied by the reduction of the meat and dairy product consumption in 2013 and 2014. The highest value in 2014 had the total surface of housing units according to which the cluster ranked the $2^{\text {nd }}$ after the cluster 2. In 2015 the reduction of the sum of the mean standard values of the indices was observed.

Using the example of the cluster 3 the consequences of the crisis reflected quite vividly as the reduction of the values of a large number of the parameters in comparison with 2014 and the growth rate of the rest of the indices decelerated. The largest reduction was seen in the average standard values of the index "total area of the housing units per capita".

One of the outsiders of the development of the consumer market is cluster 4.

Its "nucleus" consists of 11 regions (republics of Kalmykia, Mordovia, Udmurtia, Mari El, Chuvash, Khakassia, Altai Krai, Omsk, Kirov, Kurgan and Orenburg oblasts). The "sub nucleus" is made of 6 regions (Saratov, Novosibirsk, Tomsk oblasts, republic of Altay, Buryatia, Zabaikalsky krai). The total number of the regions in the cluster in 2010 and 2013 made up 19 units, in 2014 reached 26, in 2015 its number was 22 .

During the whole period under analysis the cluster had relatively low values of the largest part of the parameters of the consumer market development. At the same time the specificity of a cluster are relatively high values of the total area of housing units per capita. The meat consumption during 2010-2014 was high enough. The reduction of the both indices was observed in 2015.

Cluster 5 includes an insignificant number of regions and does not present a considerable interest for the scientific analysis.

\section{CONCLUSION}

The generalization of the information mentioned above allows making the following conclusions.

In various macroeconomic and political situations the consumer market of the regions of Russia considerably varies according to the general level of development and structure.

The regions leaders keep their dominating position at different changes of the economic and political situation.

During the period of the economic growth the regions having the positions of the outsiders move closer to the group of leaders. At the same moment the total level of the consumer market between clusters changes insignificantly. The changes affect first of all the regions of an average level of the economic development which during the period of the growth of the economic production has the positions close to the regions -leaders. During the period of the worsening of the economic situation the share of the regions - outsiders grow at the expense of the regions with an average level of the development of the consumer market.

The structural changes are typical of the regions of any level of the economic development. To the fullest extent the condition of the market worsens in compliance with the index of the consumption of the goods of the "dual use" (consumption and investment) presented in our research i.e. the area of the housing units per capita.

In the regions with a low level of the economic development a relative reduction of the consumption is observed upon the criteria of the first need food products i.e. in our case it is the index of meat consumption.

\section{References}

[1] Keynes J. M. The General Theory of Employment, Interest, and Money. Pelgrave McMillan, 1936 [Russ. Ed. John M. Keynes. Antologiya ekonomicheskoi mysli. V 2-kh tomakh. T. 2. Antology of the economic thought. In two volumes. Vol. 2. Moscow: Ekonov Publ., 1993, pp. 137434].

[2] Stiglitz J. Price of Inequality. How today's divided society endangers our future. W.W. Norton \& Company, 2012. [Russ. Ed. J.E. Stiglitz. Tsena neravenstva. Chem rassloenie obshchestva grozit nashemu budushchemu. Price of Inequality. How today's divided society endangers our future. Moscow: Izdatelstvo "E", 2017, 512 p.]

[3] Weber Max. Economy and Society. An Outline of Interpretative Sociology. University of California Press, 1978. [Russ Ed. Max Weber. Khozyaistvo i obshchestvo: ocherki ponimayushchei sotsiologii. Economy and Society. An Outline of Interpretative Sociology. Moscow: Izdatel'skii dom Vysshei shkoly ekonomiki, 2017, 429 p.]

[4] Maria Tabachnikova, Yury Treshchevskiy, Galina Frankovskaya, Yulia Vertakova, Olga Sogacheva. Economic and institutional development of Russian regions in the context of the global socio-economic processes. Globalization and its socio-economic consequences. 17th In-ternational Scientific Conference. University of Zilina, The Faculty of Operation and Economics of Transport and Communications, Department of 4th 5th October 2017. Rajecke Teplice, Slovak Republic, Part VI, pp. 26422649.

[5] Yuri Treshchevskiy, Larisa Nikitina, Mikhail Litovkin, Valentina Mayorova. Results of Innovational Activities of Russian Regions in View of the Types of Economic Culture. Russia and the European Union Development and Perspectives Part of the series Contributions to Economics. Book. Contributions to Economics, 2017, pp. 47-53.

[6] Mandel I.D. Cluster analysis. Moscow: Finansy i Statistika Publ., 1988, $176 \mathrm{p}$.

[7] Oldenderfer M.S., Blashfield R.K. Cluster analisis. Factor, discriminant and cluster analisis. Editor I.S. Yeniukov. Moscow: Finansy i Statistika Publ., 1989, 215 p.

[8] Hartigan I.A. Algoritm AS 136: A K-Means Clustering Algorithm. Eds.: J.A. Hartigan, M.A. Wong. Journal of the Royal Statistical Society Series C. Applied Statistic, 1979, Vol. 28, № 1, pp. 100-108

[9] Golichenko O.G., Shchepina I.N. Analiz rezul'tativnosti innovatsionnoi deyatel'nosti regionov Rossii [Analysis of results of the innovative economy of the regions of Russia]. Ekonomicheskaya nauka sovremennoi Rossii [Economic science of modern Russia], 2009, № 1 (44), pp. 77-95.

[10] Regiony Rossii. Sotsial'no-ekonomicheskie pokazateli. 2016. Stat. sb. [Regions of Russia. Social and Economic indices. 2016. Statistical bulletin]. Moscow: Rosstat, 2016, pp. 228 - 231; 268 - 269; 284 - 287; $302-303 ; 901-902 ; 980-993$. 